As with all the establishments of the Department of Scientific and Industrial Research, a large proportion of the time has to be devoted to answering inquiries and carrying out ad hoc investigations associated with them, and representatives of the Station sit on some forty-five committees of the British Standards Institution and other bodies.

At the present time the bulk of the work of the Station is being carried out in temporary laboratories, which it is hoped to replace by permanent buildings in the near future. It may be recalled in this connexion that it was announced last year that the Department of Scientific and Industrial Research and Fire Offices' Committee had agreed that new buildings and equipment should be provided at a cost of up to $£ 365,000$.

2 Ministry of Works Post-War Building Studies No. 20. (H.M. Stationery Office, 1946.)

\title{
OBITUARIES
}

\section{Mr. W. N. Edwards}

WILFRED NormaN EDWARDS, formerly keeper of the Department of Geology in the British Museum (Natural History), died suddenly on December 17 at the age of sixty-six. He was the second of three brothers, all of whom obtained distinction in a branch of natural science: the eldest, Fred, as an entomologist; the youngest, Donald, as an astronomer. Wilfred was educated with his two brothers at the Cambridge and County School, which at this time produced an outstanding group of naturalists, four of the boys, including the two elder Edwards, later joining the scientific staff of the British Museum (Natural History). Edwards gained a scholarship to Christ's College, and while at Cambridge came under the influence of the late Sir Albert Seward, an influence which determined his career as a palæobotanist.

After graduation, he successfully competed for a post on the scientific staff of the British Museum (Natural History) and joined the Department of Geology in 1913. The rather austere atmosphere then prevailing in the Museum seems to have weighed heavily on the young man, and he welcomed the break afforded by military service in the First World War. He served with the R.A.M.C. in the Balkans, and his experiences there certainly gave him a taste for travel in those parts, which later he fully indulged. On returning to the Museum after the War, Edwards, who was the first palæobotanist to be appointed to the staff, set about putting in order the gigantic but hitherto neglected collection of fossil plants, a task which he carried out admirably, for it was in curatorial rather than in research work that he excelled. Indeed, scientific research never seems to have been his major interest, although he was the author of more than forty publications-most of them brief-covering a wide range of palæobotanical subjects from all geological periods and notable for their painstaking accuracy. In later years more general topies, especially the historical side of palæontology, engaged his attention and he wrote an excellent little book as a guide to a special exhibit in the Department on the early history of palæoontology. He was awarded the Lyell Fund by the Geological Society in 1933, and the Lyell Medal in 1955 , in which year he was president of Section C (Geology) of the British Association.

In 1931 Edwards became deputy keeper of the Department, and thereafter administrative duties claimed much of his time. Late in $\mathbf{1 9 3 8}$ he succeeded Dr. W. D. Lang as keeper. It was a frustrating time in which to succeed to office; instead of being able to put into practice his plans, especially for the development of the exhibition galleries, the whole of his attention was absorbed in arranging for the evacuation of the principal part of the collections and for the protection of the remainder. That so little of importance was lost, in spite of the extensive damage done to the building, was in no small measure due to his untiring efforts. The War ended, Edwards threw himself whole-heartedly into the work of reconstruction, and some of the most successful new exhibits, such as that in the Succession of Life Gallery, are due to his inspiration. Further, during the last years of his keepership he was responsible for the Department's new series of explanatory booklets or guides, which have become 'best-sellers', and did much to foster the production of a number of scientific publications, including the Geological Series of the Museum Bulletin. As an editor of scientific matter he was outstanding, and any publications for which he was responsible were excellent in format and quality.

Although little inclined to committee work, he served during the War as secretary of the Geologicel Society, and afterwards as a vice-president.

Kindly, and to his junior staff even indulgent, Edwards had on occasion a sharp tongue in controversy. But his criticisms were never pointless, and his most caustic humour was usually accepted with good grace as the price of worth-while advice. Edwards was essentially an individualist, and his dislike of the formal and orthodox was shown in many ways, not least perhaps in his strong agnosticism. By nature rather solitary, he admitted few to intimate friendship. One of his closest friends was the late W. B. Honey, keeper of ceramics at the Victoria and Albert Museum. Their association reflected, like the life-long interest in folk-dancing, his strong leaning towards the arts and crafts, in which he was given to experimenting in his own Department. His satisfaction in the results was often proportional to the surprise of his more conventional colleagues.

Edwards was very much a 'character', and his loss will be deeply felt for, in spite of his reserve, he was held in esteem and affection by his staff. He leaves a widow and a son.

E. I. White

\section{Prof. Methodi Popoff}

IT has been ascertained that Methodi Popoft, Bulgaria's foremost biologist, has died within recent years. As a son of a successful physician, he had his early training at the University of Sofia. Later, the king, Czar Ferdinand, himself an enthusiastic student 
of the Lepidoptera, sent him to Munich (about 1904) to finish his training in Richard Hertwig's institute. Here he took his doctorate with a thesis on the cytology of the prosobranch Paludina. His great ability and fine personality secured for him an assistantship and later 'habilitation' as Privatdozent in the University of Munich, a rare honour for a foreigner. During the following years he worked mostly on the physiology of growth and reproduction in Paramecium, inspired by Hertwig's ideas on the meaning of the nucleo-plasmic ratio. Some of this work, published in a series of elaborate papers, has become classic, and essential conclusions have only recently been confirmed in cell-physiological work. This work was interrupted by the Balkan wars. He returned to Bulgaria and became soon the senior medical officer in the army and did outstanding work for his country in very trying situations.

After the war Popoff was appointed professor of zoology in the University of Sofia. He served also as rector of the University and played an important part in the scientific life of Bulgaria. His research work dealt mainly with problems of the chemical stimulation of growth, on which he published extensively in an era before the discovery of auxins and growth hormones. At this time he was attracted to politics as a friend of the young Czar Boris, who sent him as ambassador to Berlin after the First
World War, a position which he filled until the advent of the Nazis. In his modest legation he fixed up a small laboratory and every morning from 4 a.m. until breakfast-he never slept more than four hours -he was zoologist and worked on growth problems. For the rest of the day he was diplomat, and a very good one, due to his quiet but very able personality and his unusual charm. His legation became a centre of social life, where one could always meet the leaders of science and art in addition to the figures of political life. He was helped in this role by his German wife and by his linguistic ability (German, French, English, Turkish, Russian, Greek, Serbian).

In the early thirties Popoff fell out with the changed policies in Bulgaria and was recalled. When the King joined the Nazis he broke with him, and his courageous stand saved him later when Bolshevism took over. Before the Second World War he had been given a research institute in Sofia, where, with his usual energy, he started work in genetics (a few papers on Drosophila were published). After the revolution he was allowed to work there for some time and was treated rather respectfully. Then the iron curtain went down and nothing more was heard of him. The few of us left who knew him well remember him affectionately as a fine scholar and idealist, a man of character and a charming friend.
RICHARD GOLDSCHMIDT

\section{NEWS and VIEWS}

\section{Electrical Research Association: Dr. H. G. Taylor}

THe appointment is announced of Dr. H. G. Taylor to the office of director of the British Electrical and Allied Industries Research Association in succession to the late Dr. Stanley Whitehead. For the past nine years, Dr. Taylor has served as director of another research organization, the British Welding Research Association. Dr. Taylor graduated in the Faculty of Engineering in the University of London in 1926, and in the following year was awarded the diploma of the Imperial College. Following a College apprenticeship with the Metropolitan-Vickers Electrical Co., Ltd., he joined the scientific staff of the Electrical Research Association, where for fully eight years he was engaged in investigations concerned largely with problems of safety, earthing, and earth currents in electrical systems. For his published work in this field the degree of D.Sc. (Engineering) was conferred on him by the University of London in 1940. During 1938-43 Dr. Taylor occupied the post of electrical engineer to the Copper Development Association, where he was concerned with problems in the application of copper and its alloys in the electrical industry. He joined in 1943 the Philips organization, in which he was responsible for development work in industrial electronics and in electric welding. As director of the British Welding Research Association Dr. Taylor has had a wide experience of the administration of a research association serving a rapidly developing industry. $\mathrm{He}$ rejoins the Electrical Research Association at a time when that body has entered upon a new phase of development in the laboratories recently built at Leatherhead.

\section{British Agricultural and Food Attaché :}

Mr. M. Whalley Taylor, M.B.E.

Mr. M. Whalley Taylor, chief poultry advisory officer for the West Midland province of the National Agricultural Advisory Service, has been appointed agricultural and food attaché to H.M. Ambassadors at Copenhagen and the Hague. He will also hold $\mathbf{a}$ watching brief on technical agricultural developments and food trade trends in Western Germany. Mr. Whalley Taylor is forty-six. He was educated at Queen Elizabeth's Grammar School, Blackburn, and at Emmanuel College, Cambridge, where he took a B.A.(Agric.) degree in 1932 and an M.A. degree in 1936. During 1932-40 he farmed on his own account, after which he was appointed senior biology master at the Royal Grammar School, Clitheroe. During 1943-46 he was technical adviser and director of the experimental research farm for the Poultry Association of Great Britain. In 1946, Mr. Whalley Taylor was appointed to the staff of the Ministry of Agriculture and Fisheries as a county poultry advisory officer in the National Agricultural Advisory Service. $\mathrm{He}$ served as deputy agricultural attaché at the British Embassy in Washington during 1949-53. During this period he was promoted, and, on his return to England, was appointed chief poultry advisory officer for the West Midland province, in which post he has served until his recent appointment. $\mathrm{He}$ was made M.B.E. in 1954.

\section{The Rockefeller Institute, New York}

Prof. Edward I. TATum has been appointed a member of the Rockefeller Institute, New York. Prof. Tatum, who has been professor of biochemistry 